\title{
IDENTIFIKASI KEMAMPUAN DRIBBLING SISWA PESERTA SELEKSI GALA SISWA INDONESIA TINGKAT KOTA YOGYAKARTA
}

\section{THE IDENTIFICATION OF THE STUDENTS' DRIBBLING SKILL PARTICIPATING IN GALA SISWA INDONESIA AT JUNIOR HIGH SCHOOL LEVEL IN YOGYAKARTA CITY}

\author{
Wahyu Wibowo Eko Yulianto
}

Fakultas Teknik Industri, Universitas Pembangunan Nasional “Veteran” Yogyakarta, Indonesia

*Corresponding Author: Wahyu Wibowo Eko Yulianto, wahyu.wibowo@upnyk.ac.id

Received: 2021-05-07; Revised: 2021-07-29; Accepted: 2021-07-29

\begin{abstract}
Abstrak
Penelitian bertujuan untuk mengidentifikasi kemampuan dribbling siswa peserta seleksi Gala Siswa Indonesia jenjang Sekolah Menengah Pertama tingkat Kota Yogyakarta. Penelitian ini merupakan penelitian deskriptif kuantitatif dengan metode survey. Instrumen penelitian menggunakan tes dribbling (Nurhasan). Subjek penelitian adalah siswa peserta seleksi Gala Siswa Indonesia jenjang Sekolah Menengah Pertama tingkat Kota Yogyakarta berjumlah 25 siswa dengan menggunakan teknik total sampling. Teknik analisis data menggunakan analisis deskriptif presentase dan tabel norma tes dribbling. Hasil menunjukan kemampuan teknik dribbling siswa seleksi Gala Siswa Indonesia jenjang Sekolah Menengah Pertama tingkat Kota Yogyakarta berada dalam kategori sangat baik sebanyak 6 siswa atau 24\%, dalam kategori baik sebanyak 10 siswa atau 20\%, dalam kategori cukup baik sebanyak 5 siswa atau 20\%, dalam kategori kurang sebanyak 4 siswa atau 16\%, dan dalam kategori sangat kurang sebanyak 0 siswa atau $0 \%$. Berdasarkan nilai rata-rata tes kemampuan dribbling siswa peserta seleksi Gala Siswa Indonesia jenjang Sekolah Menengah Pertama tingkat Kota Yogyakarta sebesar 15,44 dapat ditarik kesimpulan bahwa kemampuan teknik dribbling peserta seleksi Gala Siswa Indonesia jenjang Sekolah Menengah Pertama tingkat Kota Yogyakarta berada dalam kategori Baik. Faktor-faktor yang mempengaruhi dalam kemampuan teknik dribbling seperti latihan, fisik (kecepatan, kelincahan, kekuatan otot tungkai, koordinasi mata kaki, dan keseimbangan), dan mental pemain dalam menjalani tes.
\end{abstract}

Kata Kunci: sepak bola, menggiring, gala siswa indonesia

\begin{abstract}
The research aims to identify the students' dribbling skill participating in Gala Siswa Indonesia at junior high school level in Yogyakarta city. The research is a descriptive quantitative conducted by using a survey method. The instrument of the research used the dribbling test (Nurhasan). The subjects of the research were the students participating in Gala Siswa Indonesia at junior high school level in Yogyakarta city amounted to 25. The data analysis technique used the dribbling test norm table and percentage descriptive analysis. The measurement showed that the dribbling technical skill of the students participating in Gala Siswa Indonesia at junior high school level in Yogyakarta city consisted of 6 students or $24 \%$ is in a very good category, 10 students or 20\% is in a good category, 5 students or 20\% is in enough category, 4 students or $16 \%$ is in a poor category and 0 or $0 \%$ is in a very poor category. Based on the average test score of the students' dribbling skill participating in Gala Siswa Indonesia at junior high school level in Yogyakarta city which is 15,44 is concluded that the technical skill of the students participating in Gala Siswa Indonesia at junior high school level in Yogyakarta city is in a good category. The factors which affect the dribbling technical skill are exercise, physical (speed, agility, leg muscle strength, ankle coordination, and balance) and the player's mental abilities in doing the test.
\end{abstract}

Keywords: soccer, dribbling, gala siswa Indonesia 
How To Cite: Yulianto, W.W.E. (2021). Identifikasi kemampuan dribbling siswa peserta seleksi gala siswa indonesia tingkat kota yogyakarta. Journal Of Sport Education (JOPE), 4 (1), 1 9.doi:http://dx.doi.org/10.31258/jope.4.1.1-9

\section{PENDAHULUAN}

Pandemi Covid-19 sedang melanda Dunia, semua sektor terkena dampaknya. Salah satunya bidang olahraga khususnya sepak bola. Federasi sepak bola eropa atau yg dikenal dengan UEFA (Union of European Football Associations) mengumumkan bahwa event Euro 2020 telah ditunda hingga musim panas 2021(Susanto, 2020). Kemudian event Copa Amerika dan Olimpiade Tokyo juga ditunda. Sedangkan di Indonesia sendiri liga sepak bola semua berhenti. Hal ini mengakibatkan kerugian pada pihak atlet, pelatih, penonton dan pihak-pihak di dalamnya.

Satu-satunya kejuaraan sepak bola yang diselenggarakan adalah Gala Siswa Indonesia jenjang Sekolah Menengah Pertama. Kompetisi gala siswa Indonesia jenjang sekolah menengah pertama digelar oleh Pusat Prestasi Nasional (Puspresnas) bekerjasama dengan Persatuan Sepak bola Seluruh Indonesia dibawah Kemdikbud Republik Indonesia dalam rangka menjalankan amanah Presiden Republik Indonesia tentang Percepatan Pembangunan Persepakbolaan Nasional (Nasional et al., 2020). Gala Siswa Indonesia merupakan ajang bagi para siswa tingkat Sekolah Menengah Pertama menunjukan bakat di bidang sepak bola. Hasil dari kejuaraan ini nantinya akan menjadi referensi bagi Persatuan Sepak Bola Indonesia dalam menyeleksi tim nasional usia 16 tahun (Nasional et al., 2020). Kejuaraan atau seleksi pemain dalam gala siswa Indonesia dilaksanakan dengan sistem daring atau dalam bentuk video pemain. Pengambilan video video seleksi secara akurat menentukan sistem seleksi ini (Sen \& Deb, 2021).

Daerah Istimewa Yogyakarta sendiri setiap tahun selalu berpartisipasi dalam gelaran Gala Siswa Indonesia khususnya Kota Yogyakarta. Dinas Pendidikan bekerjasama dengan Musyawarah Guru Mata Pelajaran Kota Yogyakarta menjadi fasilitator kegiatan seleksi dari tingkat kecamatan sampai tingkat kabupaten. Kegiatan ini diikuti oleh siswa kelahiran maksimal 2006 yang berasal dari sekolah negeri dan swasta yang terdaftar dalam data pokok peserta didik. Setiap sekolah atau kecamatan mengirimkan 18 siswa sebagai perwakilan tiap kecamatan yang melalui seleksi tingkat kecamatan. Di tingkat kabupaten/kota ini nantinya akan terpilih 18 pemain dan 2 penjaga gawang yang akan maju ke tingkat propinsi.

Kompetisi yang biasanya dilakukan dengan seleksi melalui pertandingan akhirnya menggunakan mekanisme baru yang merupakan bentuk adaptasi kebiasaan baru dalam masa pandemi dengan sistem daring. Hal ini menjadikan kekhawatiran dalam banyak kalangan bahwa olahraga tim dilakukan dengan seleksi individu dengan kemampuan fisik, teknik dan karakter pemain tanpa melalui pertandingan. Namun hal tersebut terjawab dalam petunjuk teknis dan petunjuk pelaksanaan bahwa mekanisme baru ini sudah digambarkan instrumen keterampilan sepak bola yang dapak dilakukan secara daring dan sudah sesuai dengan komponen dalam sepak bola (Nasional et al., 2020). Ditambahkan oleh (Mohammed, 2016) bahwa melihat perkembangan pemian dapat dilakukan secara virtual. Sehingga diharapkan menjadi instrumen paduan untuk guru dan pelatih ekstrakurikuler dalam menyeleksi ditingkat kecamatan hingga provinsi.

Sepak bola merupakan cabang olahraga yang komplek, kombinasi dari beberapa aspek fisik, teknik, taktik dan mental (Yulianto, 2020). Olahraga sepak bola olahraga serba cepat, tidak teratur dan multireksional selama pertandingan (Field et al., 2020). Sepak bola sendiri merupakan olahraga permainan yang dimainkan oleh 2 tim terdiri dari 11 lawan 11 dengan satu bola dan mengembangkan aksi (Danurwindo et al., 2017). Komponen dalam teknik sepak bola meliputi: teknik gerakan tanpa bola (lari, melompat dan gerak tipu), teknik gerakan dengan bola (ball control, dribbling, passing,juggling, throw-in, sliding tacle-shielding heading, 
goalkeeping, dan shooting). Tidak hanya itu teknik sepak bola juga didukung oleh faktor fisik, strategi dan mental. Sepak bola merupakan cabang olahraga membutuhkan pembinaan berjenjang dan berkelanjutan yang dilaksanakan secara profesional. Begitu juga dengan tahap seleksi pemain dalam gala siswa Indonesia sebagai pemanduan bakat dibidang sepak bola. Untuk itu komponen yang ada dalam sepak bola menjadi hal yang krusial dalam melihat kualitas dari individu pemain yang seperti dari aspek fisik, teknik, curiculum vitae pemain.

Pada tingkat kabupaten ini khusus untuk posisi pemain yang dinilai adalah fisik, aspek teknik, dan yang ketiga adalah curiculum vitae yang terdiri dari pengalaman dan prestasi individu pemain (Nasional et al., 2020). Dari rangkaian tes tersebut, peneliti ingin melengkapi dalam hal tes dribbling, hal tersebut dikarenakan belum masuknya tes dribbling dengan bola dalam rangkaian tes tersebut, mengingat dominannya kemampuan dribbling seorang pemain. Dalam sebuah penelitian juga dikatakan bahwa dalam sebuah kompetisi persiapan dan kompetisi diketahui bahwa teknik assist, umpan satu-dua dan dribbling menjadikan penampilan tim lebih baik dalam menjalani kompetisi (George et al., 2014). Kompetisi ini juga akan menentukan menunjukan keterampilan hasil latihan dari peserta (Ferraz et al., 2019).

Teknik dribbling adalah suatu teknik yang paling dominan untuk menyerang bertahan maupun transisi (Marta \& Oktarifaldi, 2020). Dribbling sendiri adalah teknik untuk memindahkan bola menggunakan kaki dari satu tempat ke tempat yang lain untuk mencapai tujuan mengadakan serangan balik, melewati lawan, dan mencetak gol ke gawang lawan (Arwandi \& Firdaus, 2021). Teknik dribbling juga digunakan sebagai kontrol atau tempo sebuah pertandingan (Mohammed \& Ali, 2015). Lebih lanjut dalam keadaan atau usaha membangun sebuah serangan diawali dengan aksi salah satunya dengan dribbling (Danurwindo et al., 2017). Dengan melihat dominannya kemampuan dribbling yang harus dimiliki pemain dalam sebuah tim, perlu digali bagaimana hasil dari kemampuan dribbling siswa peserta Gala Siswa Indonesia jenjang Sekolah Menengah Pertama tingkat Kota Yogyakarta. Kemudian perlu dikaji juga secara literatur atau penelitian terdahulu berkaitan dengan faktor-faktor penunjang kemampuan dribbling tersebut. agar nantinya menjadi informasi yang lengkap dalam mendeskripsikan kemampuan teknik dribbling bola ini.

Dari perspektif praktis, hasil uji lapangan merupakan pengukuran yang handal dan hemat waktu gaya untuk menilai kinerja fisik di masa muda (Siirt, 2016). Ditambah dengan periode usia ini adalah masa menguntungkan digunakan sebagai pengembangan keterampilan dalam sepak bola. Penilaian dalam seleksi gala siswa indonesia menjadi tolak ukur kemajuan dari hasil latihan pemain dan menentukan posisi kemampuannya (Fenanlampir\&Faruq, 2015). Informasi tentang kemampuan dribbling peserta seleksi gala siswa indonesia akan melengkapi hasil-hasil rangkaian tes yang lain, sehingga menjadi semakin lengkap dalam melihat hasil seleksi pemain yang berkualitas yang akan berlaga di tingkat propinsi nantinya. Hasil penelitian ini menjadi bahan acuan dan evaluasi bagi peserta dan pelatih sepak bola di lingkungan sekolah dan di klub usia dini. Berdasarkan hal tersebut fokus penelitian ini adalah identifikasi kemampuan dribbling siswa peserta seleksi gala siswa indonesia jenjang Sekolah Menengah Pertama tingkat Kota Yogyakarta.

\section{METODE}

Penelitian merupakan penelitian deskriptif kuantitatif. Penelitian mendeskripsikan tentang kemampuan menggiring bola siswa jenjang sekolah menengah pertama. Metode penelitian ini menggunakan survey. Subjek penelitian adalah siswa peserta Gala Siswa Indonesia jenjang Sekolah Menengah Pertama tingkat Kota Yogyakarta yang terdiri dari 25 siswa, sampel diambil dengan diambil dengan menggunakan teknik total sampling yaitu semua siswa dalam populasi sebagai subjek penelitian. Instrumen pengukuran kemampuan dribbling siswa menggunakan tes dribbling dengan validitas 0,979 dan reliabilitas 0,983. Tujuan tes ini adalah mengukur keterampilan menggiring bola dengan kaki secara cepat 
disertai perubahan arah. Teknik analisa data menggunakan tabel 1 norma tes dibbling kemudian dilanjtkan dengan analisis deskriptif presentase. Berikut ditampilkan rentang nilai dan kategori tes dribbling.

Tabel 1. Nilai Rentang Tes Dribbling

\begin{tabular}{cc}
\hline Rentang Waktu (detik) & Keterangan \\
\hline $17,88<$ & Sangat Kurang \\
$16,69-17,88$ & Kurang \\
$15,50-16,69$ & Cukup Baik \\
$14,31-15,50$ & Baik \\
$\leq 14,31$ & Sangat Baik \\
\hline
\end{tabular}

Sumber: (Supriyono, 2018)

Data hasil penelitian yang sudah di konversikan kedalam tabel kategori kemudian di persentasekan untuk mengetahui nilai dalam persen seperti dibawah ini (Arikunto, 2006):

$$
P=\frac{F}{N} \times 100 \%
$$

Keterangan:

$\mathrm{P}=$ Persentase yang dicari

$\mathrm{F}=$ Frekuensi

$\mathrm{N}=$ Jumlah responden

\section{HASIL}

Pengukuran kemampuan dribbling bola siswa peserta seleksi GSI SMP di tingkat Kota Yogyakarta dilakukan dengan teknis para siswa peserta seleksi mengirimkan video teknik dribbling dengan panduan teknis yang dibuat peneliti. Kemudian peneliti melakukan penilaian terhadap keabsahan dan ketepatan tes dribbling. Dari sekitar 35 pemain yang mengirimkan video, hasil penilaian tersebut terdapat 25 siswa yang memenuhi kriteria dan kemudian semua dijadikan sampel penelitian. Hasil pengukuran kemampuan dribbling bola siswa peserta seleksi Gala Siswa Indonesia jenjang Sekolah Menengah Pertama di tingkat Kota Yogyakarta berada dalam satuan waktu (detik). Gambaran deskriptif statistik seperti di tabel:

Tabel 2. Hasil pengukuran tes dribbling

\begin{tabular}{lcc}
\hline & Deskriptif & Statistik \\
\hline$N$ & 25 \\
Mean & 15,44 \\
Std. Deviation & 1,228 \\
Variance & 1,508 \\
Minimum & 14 \\
Maximum & 19 \\
Sum & 386 \\
\hline
\end{tabular}

Dari data deskriptif statistik diketahui bahwa hasil tes kemampuan dribbling bola siswa peserta seleksi Gala Siswa Indonesia jenjang Sekolah Menengah Pertama di tingkat Kota Yogyakarta berjumlah 25 siswa dengan nilai mean sebesar 15,44, nilai standard deviation 1,228 , nilai batas bawah 14 dan nilai batas atas 19 . Selanjutnya berdasarkan hasil tes dribbling bola siswa peserta seleksi Gala Siswa Indonesia jenjang Sekolah Menengah Pertama di tingkat Kota Yogyakarta, dikonversikan ke dalam tabel norma kategori kemampuan 
Journal of Sport Education (JOPE), 4 (1) 2021 - 5

Wahyu Wibowo Eko Yulianto

dribbling siswa seperti tabel 3 dibawah ini:

Tabel 3. Konversi hasil tes dribbling

\begin{tabular}{cccc}
\hline Interval (detik) & F & Persentase (\%) & Kategori \\
\hline $17,88<$ & 0 & 0 & Sangat Kurang \\
$16,69-17,88$ & 4 & 16 & Kurang \\
$15,50-16,69$ & 5 & 20 & Cukup Baik \\
$14,31-15,50$ & 10 & 40 & Baik \\
$\leq 14,31$ & 6 & 24 & Sangat Baik \\
Jumlah & 25 & 100 & \\
\hline
\end{tabular}

Kemudian data deskriptif statistik hasil tes kemampuan dribbling bola siswa peserta seleksi Gala Siswa Indonesia jenjang Sekolah Menengah Pertama di tingkat Kota Yogyakarta yang berada dalam lima kategori. Secara lebih rinci kemampuan dribbling bola peserta seleksi Gala Siswa Indonesia jenjang Sekolah Menengah Pertama di tingkat Kota Yogyakarta digambarkan dalam gambar 1 dibawah ini:

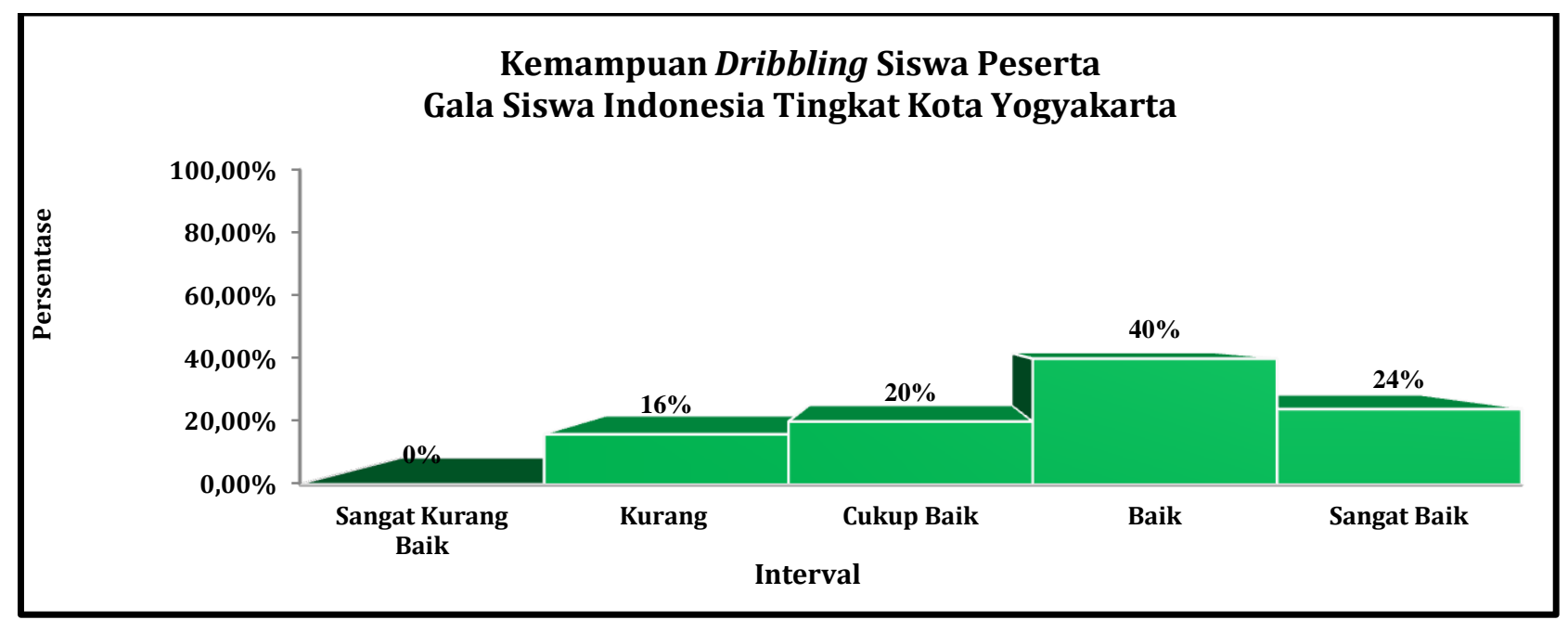

Gambar 1.Diagram Batang kemampuan dribbling bola siswa peserta seleksi Gala Siswa Indonesia jenjang Sekolah Menengah Pertama di tingkat Kota Yogyakarta

Berdasarkan tabel 3 dan diagram 1 diketahui bahwa kemampuan teknik dribbling siswa seleksi Gala Siswa Indonesia jenjang Sekolah Menengah Pertama tingkat Kota Yogyakarta adalah 6 peserta atau 24\% sangat baik, 10 peserta atau 20\% baik, 5 peserta atau 20\% cukup baik, 4 peserta atau 16\% kurang dan 0 peserta atau 0\% sangat kurang. Berdasarkan nilai ratarata tes kemampuan dribbling siswa peserta seleksi Gala Siswa Indonesia jenjang Sekolah Menengah Pertama tingkat Kota Yogyakarta sebesar 15,44 masuk dalam kategori masuk dalam kategori Baik. Secara lebih rinci akan dibahas dalam pembahasan mengenai hasil dan faktor yang mempengaruhi hasil tes dribbling.

\section{PEMBAHASAN}

Penelitian dilakukan dengan teknis daring, yaitu dengan metode siswa yang berasal dari masing-masing kecamatan di Kota Yogyakarta melakukan rekaman video teknik dribbling sesuai panduan tes yang diberikan oleh panitia. Perekaman video dilakukan di area rumah atau lapangan. Terdapat beberapa hambatan yang terjadi dalam proses seleksi gala siswa Indonesia jenjang sekolah menengah pertama, diantaranya siswa kurang percaya diri untuk mengikuti seleksi melalui perekaman video, siswa merasa kesulitan dalam melakukan rekaman video. Hal itu mengakibatkan beberapa kecamatan tidak mengirimkan wakilnya 
untuk mengirimkan video. Hasil penelitian ini merupakan hal baru dalam sistem seleksi dengan melihat keterampilan pemain sepak bola melalui video. Tim penilai menyortir video yang benar dalam kebenaran peserta melakukan tes dribbling ini.

Sepak bola dicirikan sebagai olahraga tim intermiten intensitas tinggi yang membutuhkan lompatan, menembak, tekel, berbelok, berlari cepat, mengontrol bola di bawah tekanan, berlari dengan kecepatan berbeda, dan melakukan tekel geser (Siirt, 2016). Dalam keadaan atau usaha membangun sebuah serangan diawali dengan aksi, aksi-aksi dalam sepak bola salah satunya adalah dengan dribbling (Danurwindo et al., 2017). Banyak faktor seperti keterampilan teknis, taktis, fisik dan mental dapat mempengaruhi kinerja pemain dalam sepak bola. Salah satu teknik yang dominan dalam sepak bola adalah teknik dribbling bola. Dribbling sendiri adalah kemampuan seorang pemain menguasai bola dan mampu menggiring bola dengan tujuan untuk melewati lawan, mengarahkan bola ke ruang kosong, melepaskan diri dari kawalan lawan, membuka ruang untuk kawan, serta menciptakan peluang untuk melakukan shooting ke gawang lawan. Tujuannya adalah untuk mendekati jarak kesasaran untuk melewati lawan dan menghambat permainan. Informasi tentang performa atau kinerja dribbling ini merupakan informasi berharga bagi pelatih untuk mengoptimalkan program pelatihan individu dan tim.

Nilai tes kemampuan dribbling siswa peserta seleksi Gala Siswa Indonesia jenjang Sekolah Menengah Pertama tingkat Kota Yogyakarta sebesar 15,44 masuk dalam kategori masuk dalam kategori Baik. Artinya rata-rata pemain masuk dalam rentang nilai kategori baik. hal ini perlu dikaji secara mendalam melalui penelitian-penelitian terdahulu berkaitan dengan faktor-faktor penunjang kemampuan dribbling bola pada usia yang sama yaitu 13-14 tahun.

Penelitian sebelumnya menunjukkan bahwa pemain sepak bola berusia antara 11-14 tahun lebih tinggi tingkat kinerja dalam koordinasi tungkai bawah tes dibandingkan dengan aktif secara fisik anak-anak yang termasuk dalam kelompok usia yang sama (Irkov et al., 2010). Dalam hasil penelitian (Marta \& Oktarifaldi, 2020) menyebutkan bahwa terdapat pengaruh kelincahan dan koordinasi mata kaki terhadap teknik dribbling. Hasil penelitian tersebut menunjukan bahwa periode usia 11-14 tahun merupakan periode yang baik dalam pengembangan keterampilan salah satunya koordinasi dalam hal ini berkaitan dengan kemampuan dribbling.

Hasil penelitian sebelumnya menunjukan bahwa kemampuan dribbling pemain sepak bola usia 14 tahun berhubungan dengan kecepatan, kelincahan, vertical jump (Siirt, 2016), secara keseluruhan menyarankan bahwa ketangkasan adalah faktor kunci bagi pemain muda. Kemudian pada penelitian Padron Cabo, et al meneliti bagaimana latihan 6 minggu menggunakan agility leader memberikan stimulus yang efisien terhadap kemampuan dribbling pemain sepak bola usia muda (Padrón-Cabo et al., 2020). Hal ini juga didukung oleh penelitian Setyo et, al bahwa latihan kecepatan tinggi dan rendah terdapat interaksi dan berpengaruh terhadap kemampuan dribbling pemain sepak bola. (Setyo et al., 2020). Lebih lanjut secara biomekanika dribbling bola dapat ditentutakn oleh faktor speed, agility dan kekuatan otot tungkai (Alfian Halim F, 2016) (Abidin et al., 2020). Penelitian lain menyebutkan bahwa latihan dribbling dengan keseimbangan pemain yang tinggi akan mempengaruhi hasil latihan dribbling (Syaifudin, 2016). Faktor psikologi juga mempengaruhi kondisi pemain dalam menjalankan tes dribbling tersebut. Hal tersebut dikarenakan pemain tes di lapangan dengan adanya kamera untuk merekamnya dan kepercayaan diri siswa menjadi faktor penunjang hasil tes dribbling. Sebuah penelitian menjelaskan bahwa kepercayaan diri pemain berpengaruh secara signifikan terhadap kemampuan dribbling pemain. Ketika seorang pemain gampang grogi maka kemampuannya tidak bisa di realisasikan dengan baik.

Kelincahan atau aglity digunakan dalam mengubah arah dengan cepat. Kecepatan 
digunakan pemain dalam melewati lawan dan dalam situasi serangan guna meninggalkan pemain lawan menuju ke gawang. Cepat dan lincah pemain itu akan tinggi pula kemampuan dribbling pemain itu (Alfian Halim F, 2016). Kemudian koordinasi dan kekuatan tungkai pemain digunakan untuk mengintegrasikan semua gerakan kompleks dalam sepak bola, dengan melatih keterampilan dribbling dengan metode koordinasi dapat meningkatkan kemampuan dribbling. Keseimbangan digunakan dalam melakukan gerakan melewati lawan dalam kecepatan dengan menjadi penopang agar gerakan tetap stabil. Faktor tersebut akan menunjang performa pemain dalam pertandingan.

Hasil tersebut sejalan dengan karakteristik tes dribbling yang digunakan untuk mengukur kemampuan siswa seleksi. Pertama tes ini menghasilkan waktu tercepat dalam melakukan tes, unsur kecepatan lari dengan membawa bola dipertaruhkan dalam tes ini. Kedua kelincahan yang digunakan dalam melewati rintangan yang terdiri dari enam penghalang. Ketiga kekuatan otot tungkai dan koordinasi dalam merubah teknik dribing menggunakan kaki bagian kanan dan bagian kiri. Keempat yaitu keseimbangan yaitu siswa dalam melakukan tes secara cepat dan lincah membutuhkan keseimbangan yang baik, kelima proses Latihan juga mempengaruhi kinerja pemain (Ferraz et al., 2019) dan terakhir adalah kepercayaan diri hasil dari latihan siswa yang sudah dijalani, kana terlihat bagaimana siswa yang rutin latihan di sekolah sepak bola dan tidak, kepercayaan diri juga terlihat bagaimana peserta yang mencermati contoh video tes yang akan dipraktekkan akan sangat mempengaruhi hasil atau kinerja tes dribbling (Veraksa \& Gorovaya, 2012).

Walaupun hasil masuk dalam kategori rata-rata baik, namun secara detail masih banyak pemain yang masuk dalam keadaan cukup baik dan kurang baik, artinya kemampuan tersebut belum sepenuhnya merata, perlu adanya latihan secara teknik dan mental guna meningkatkan kemampuan dribbling pemain tersebut. Latihan dribbling hendaknya dilakukan pada kedua kaki dan banyak sentuhan dengan bola dan gestur pemain juga diperhatikan. Dengan hasil ini dapat menjadi rujukan pelatih dalam meningkatkan kemampuan teknik dribbling. Karena tidak dapat dipungkiri peran pelatih dalam memotivasi peserta dan memperbaiki sistem Latihan berpengaruh dalam hasil tes keterampilan dribbling pemain (Van Yperen et al., 2021) (Esposito et al., 2019). Dilihat dari beberapa aspek dribbling, kejuaraan ini juga melihat kemampuan fisik, teknis dan mental pemain (Modric et al., 2020).

Berdasarkan penelitian tersebut dapat digambarkan bahwa kemampuan teknik dribbling siswa peserta seleksi Gala Siswa Indonesia jenjang Sekolah Menengah Pertama pada tingkat kota Yogyakarta rata-rata mempunyai kemampuan yang baik. Dilihat dari curikulum vitae yaitu pengalaman dan prestasi individu pemain, rata-rata siswa merupakan siswa sekolah sepak bola dan sudah mempunyai pengalaman banyak dalam hal latihan dan pertandingan. Dari hasil ini juga dapat dijabarkan banyak komponen biomotor yang berkontribusi pada pemain dalam merealisasikan faktor-faktor yang mempengaruhi dalam kemampuan teknik dribbling seperti latihan, fisik (kecepatan, kelincahan, kekuatan otot tungkai, koordinasi mata -kaki, dan keseimbangan), dan mental peserta dalam menjalani tes.

\section{SIMPULAN}

Berdasarkan hasil penelitian dan analisis data diketahui kemampuan dribbling siswa peserta seleksi Gala Siswa Indonesia jenjang Sekolah Menengah Pertama tingkat Kota Yogyakarta dalam kategori baik dengan nilai rata-rata sebesar 15,44. Latihan, fisik (kecepatan, kelincahan, kekuatan otot tungkai, koordinasi mata kaki, dan keseimbangan), dan mental peserta dalam menjalani tes menjadi faktor penentu hasil tes dribbling. Saran untuk penelitian selanjutnya adalah menambahkan aspek psikologis dalam instrument tes sehingga diketahui bagaimana kepercayaan diri pemain dalam melakukan tes secara daring, hal ini dikarenakan tes ini merupakan hal baru dalam seleksi keterampilan pemain sepak bola. Hasil ini juga menjadi bahan evaluasi dan alternatif bagi pelatih dan pemain dalam meningkatkan 


\section{Journal of Sport Education (JOPE), 4 (1) 2021 - 8 \\ Wahyu Wibowo Eko Yulianto}

keterampilan sepk bola khususnya teknik dribbling.

\section{DAFTAR PUSTAKA}

Abidin, D., Education, P., Haqiyah, A., Education, P., Muhamad, M., Education, P., Gusriadi, A. R., \& Education, P. (2020). Agility and Balance on the Speed of Dribbling in Soccer. 407(Sbicsse 2019), 208-210.

Alfian Halim F, M. (2016). Hubungan Antara Kecepatan Dan Kelincahan Terhadap Kemampuanmenggiring Pada Pemain Sepakbola Gpd Sidoarjo U - 15. Jurnal Kesehatan Olahraga, 4(4).

Marta, I. A., \& Oktarifaldi, O. (2020). Koordinasi Mata-Kaki Dan Kelincahan Terhadap Kemampuan Dribbling Sepakbola. Pendidikan Jasmani Dan Olahraga, 4(3), 1-14.

Arwandi, J., \& Firdaus, M. (2021). Effect of Agility Training Towards Soccer Dribbling Skills. 35(Icssht 2019), 7-10. https://doi.org/10.2991/ahsr.k.210130.002

Danurwindo, Ganesha, P., Barry, S., \& Prahara, J. L. (2017). Kurikulum Pembinaan Sepakbola Indonesia PSSI. 5.

Yulianto, W. W. E. (2020). Identifikasi keberbakatan sepak bola pada siswa sekolah sepak bola hizbul wathan yogyakarta. Journal of Sport Education (JOPE), 2(2), 47. https://doi.org/10.31258/jope.2.2.47-54

Esposito, G., Ceruso, R., \& Isanto, T. D. (2019). Original Article Evaluation of some quantitative aspects in the young soccer players training process during puberty. 19(5), 1777-1783. https://doi.org/10.7752/jpes.2019.s5261

Fenanlampir, Albertus \& Faruq, M. Muhyi. (2015). Tes dan pengukuran dalam olahraga. Yogyakarta: Andi Offset

Ferraz, R. M. P., van den Tillaar, R., Pereira, A., \& Marques, M. C. (2019). The effect of fatigue and duration knowledge of exercise on kicking performance in soccer players. Journal of Sport and Health Science, 8(6), 567-573. https://doi.org/10.1016/j.jshs.2016.02.001

Field, A., Naughton, R. J., Haines, M., Lui, S., Corr, L. D., Russell, M., Page, R. M., \& Harper, L. D. (2020). The demands of the extra-time period of soccer: A systematic review. Journal of Sport and Health Science, 00. https://doi.org/10.1016/j.jshs.2020.03.008

George, S., Ionel, M., \& Cristian, P. (2014). A Comparative Study on the Evolution of the Parameters in Professional Soccer Matches. Procedia - Social and Behavioral Sciences, 127, 63-67. https://doi.org/10.1016/j.sbspro.2014.03.213

Irkov, D. R. M. M., Ukolj, M. I. K., Garkovic, D. U. U., \& Oprivica, V. L. J. K. (2010). D a p p p y e $m s$ p a ls. 24(10), 2677-2682.

Modric, T., Versic, S., \& Sekulic, D. (2020). Aerobic fitness and game performance indicators in professional football players; playing position specifics and associations. Heliyon, 6(11). https://doi.org/10.1016/j.heliyon.2020.e05427 
Mohammed, Z. (2016). Which visual sight skill tested and developed the interaction between central and peripheral vision case duels dribbling soccer skills. International Journal of Applied Exercise Physiology, 5(3), 31-37.

Mohammed, Z., \& Ali, B. (2015). the Impact Dimensional of Delimiters on Testing and Training Duels Dribbling in Young Soccer (Under 15 Year). European Scientific Journal, OCTOBER.

Nasional, P. P., Jenderal, S., Pendidikan, K., \& Kebudayaan, D. (2020). Panduan teknis pelaksanaan. $61,1-27$.

Padrón-Cabo, A., Rey, E., Kalén, A., \& Costa, P. B. (2020). Effects of Training with an Agility Ladder on Sprint, Agility, and Dribbling Performance in Youth Soccer Players. Journal of Human Kinetics, 73(1), 219-228. https://doi.org/10.2478/hukin-2019-0146

Syaifudin, R. (2016). Pengaruh Metode Pembelajaran Eksplorasi Dan Kelincahan Siswa Terhadap Hasil Belajar Permainan Sepakbola. Journal of Physical Education and Sports, 5(2), 89-95.

Sen, A., \& Deb, K. (2021). Categorization of actions in soccer videos using a combination of transfer learning and Gated Recurrent Unit. ICT Express, $x x x x$. https://doi.org/10.1016/j.icte.2021.03.004

Setyo, E. B., Hartono, M., \& Rustiadi, T. (2020). Influence of Training Method and Running Speed Toward Ball Dribbling Skill Improvement of Soccer Extracurricullar Students of The Whole 02 Cluster of JHS Students in Semarang. 9(16), 1-7.

Siirt, A. (2016). The Relationships among Acceleration, Agility, Sprinting Ability, Speed Dribbling Ability and Vertical Jump Ability in 14-Year-Old Soccer Players Old Soccer Players. 3(May), 29-34. https://doi.org/10.9790/6737-03022934

Supriyono, E. (2018). Pengembangan aplikasi tes keterampilan sepakbola berbasis web Developing web-based soccer skills test application. Jurnal Keolahragaan, 6(1), 38-47.

Susanto, N. (2020). Pengaruh virus covid 19 terhadap bidang olahraga di indonesia. JURNAL STAMINA, $3(3)$, 145-153. http://stamina.ppj.unp.ac.id/index.php/JST/article/view/491/239

Van Yperen, N. W., Dankers, S., Elbe, A. M., Sanchez, X., \& Otten, S. (2021). Perceived inclusion in youth soccer teams: The role of societal status and perceived motivational goal climate. Psychology of Sport and Exercise, 53(May 2020), 101882. https://doi.org/10.1016/j.psychsport.2020.101882

Veraksa, A., \& Gorovaya, A. (2012). Imagery training efficacy among novice soccer players. Procedia - Social and Behavioral Sciences, 33, 338-342. https://doi.org/10.1016/j.sbspro.2012.01.139 